\title{
PERAN HUMAS PT. PERTAMINA (PERSERO) DALAM MEMBANGUN KOMUNIKASI DUA ARAH YANG EFEKTIF
}

\author{
Riastri Novianita \\ Cindya Yunita Pratiwi \\ Fakultas Ilmu dan Bahasa, Universitas Bina Sarana Informatika \\ riastri.rsv@bsi.ac.id, cindya.cyp@bsi.ac.id
}

\begin{abstract}
PT. Pertamina (Persero) as a large company engaged in the field of fuel oil and LPG products, it sure to make contact with customers such as how to handle all forms of customer questions and complaints and establish relationships with the surrounding community. This is important as an effort to improve a good image in the eyes of the community. Therefore the need for effective two-way communication. This type of research is qualitative research, in collecting data researchers conduct research and also study existing documents. Using the case study method because researchers want to describe the existing phenomena as well as describe in depth related to how public relations PT. Pertamina (Persero) build effective communication. From the research results obtained, that in implementing good communication, public relations PT.Pertamina (Persero) facilitates customers by creating customer service "customer care 135", besides that in facilitating access the SPBU digitalization program has been running which is expected to make it easier for consumers to get information. PT Pertamina (Persero) also does not forget to surrounding community by providing assistance as the context of prevention and covid-19 handling in several work areas.
\end{abstract}

Key word: The role of $P R$, building communication, two ways

\begin{abstract}
Abstrak
PT. Pertamina (Persero) sebagai perusahaan besar yang bergerak di bidang produk Bahan Bakar Minyak dan LPG, tidak dipungkiri akan melakukan kontak dengan pelanggan seperti bagaimana dalam menghandel segala bentuk pertanyaan dan keluhan pelanggan serta menjalin hubungan dengan masyarakat sekitar. Hal ini penting sebagai upaya untuk meningkatkan citra yang baik di mata masyarakat. Maka dari itu diperlukannya komunikasi dua arah yang efektif. Jenis penelitian ini termasuk kedalam penelitian kualitatif, dalam mengumpulkan data peneliti melakukan penelitian dan juga studi dokumen yang ada. Menggunakan metode studi kasus karene peneliti ingin menguraikan bentuk fenomena yang ada serta menguraikan secara mendalam terkait bagaimana humas PT. Pertamina (Persero) membangun komunikasi. Dari hasil peneltian yang didapat, bahwa dalam menerapkan komunikasi yang baik, humas PT. Pertamina (Persero) memfasilitasi para pelanggan dengan menciptakan layanan pelanggan "customer care 135", selain itu dalam memudahkan
\end{abstract}


akses telah berjalan program digitalisasi SPBU yang diharapkan akan mempermudah konsumen dalam mendapatkan informasi. PT. Pertamina (Persero) juga tidak lupa dengan masyarakat sekitar dengan memberikan bantuan dalam rangka pencegahan dan juga penanganan covid-19 ke beberapa wilayah area kerja.

Kata kunci: Peran Humas, membangun komunikasi, dua arah

\section{PENDAHULUAN}

Istilah komunikasi pertama kali muncul dari bahasa latin yaitu Communicatio, yang memiliki arti bahwa memiliki satu makna terhadap suatu hal (Effendy, 2005: 3). Menurut para ahli pengertian komunikasi sendiri banyak, namun secara umum jika dilihat arti dari komunikasi adalah proses penyampaian pesan oleh satu pihak (orang) kepada pihak lain (orang lain) untuk memberi tahu, mengubah sikap, pendapat, perilaku yang dilakukan langsung (secara lisan) maupun tidak langsung yaitu melalui media (Effendy, 2005: 5). Dalam keseharian komunikasi sering dilakukan yaitu dimana seseorang akan memberikan sebuah pesan kepada orang lain kemudian pesan tersebut akan disampaikan oleh pengirim kepada penerima melalui media.

Komunikasi terbagi ke dalam beberapa konteks yaitu komunikasi interpersonal, komunikasi intrapersonal, komunikasi kelompok, komunikasi organisasi, dan komunikasi massa. Jenis ini dapat dilihat melalui pendekatan yang dilakukan oleh pelaku komunikasi. Sementara konteks komunikasi pada penelitian ini adalah komunikasi organisasi. Media yang digunakan pada komunikasi organisasi khususnya dalam membangun komunikasi dua arah dapat bermacam-macam diantaranya adalah telepon atau Hand phone yang dapat digunakan bila melakukan wawancara.

Adapun judul yang diangkat pada penelitian ini adalah peran humas PT. Pertamina (Persero) dalam membangun komunikasi dua arah yang efektif. Dalam hal ini yang dimaksud dengan efektif yaitu berperan penting komunikasi dalam sebuah perusahaan yang juga termasuk dari strategi bisnis sebuah perusahaan. Hal ini dianggap penting dan sangat bermanfaat agar perusahaan dapat berjalan dengan baik dalam satu visi, misi dan tujuan perusahaan. Dalam kondisi perusahaan yang memiliki karyawan dari latar belakang yang berbeda-beda maka diharapakan dapat terbangun komunikasi yang harmonis antar anggota organisasi dalam perusahaan. Dengan 
adanya keharmonisan dalam komunikasi dalam organisasi dalam perusahaan maka diharapkan perusahaan dapat menjalankan visi, misi dan tujuannya.

Iklim komunikasi dalam sebuah perusahaan akan mempengaruhi keberhasilan atau kegagalan yang akan terjadi pada perusahaan tersebut. Oleh karena itu, perusahaan sedapat mungkin harus membangun komunikasi yang efektif dan harmonis karena omunikasi memiliki peran yang sangat penting dalam lingkungan perusahaan dan merupakan kunci awal keberhasilan.

Dalam hal ini penulis mencoba untuk meneliti peran humas PT. Pertamina (Persero) menjalankan komunikasi dua arah yang efektif. Sebagai perusahaan besar di bidang bahan bakar minyak dan gas tentu tak dipungkiri menerima sejumlah pertanyaan maupun keluhan terhadap produknya, maka dari itu humas dituntut untuk mampu berperan secara efektif dan efisien dalam berkomunikasi dua arah sehingga dapat terus menciptakan iklim citra yang positif mata masyarakat.

\section{TINJAUAN PUSTAKA}

Setiap manusia menggunakan komunikasi dalam menjalani kehidupan sehaihari. Komunikasi digambarkan sebagai proses interaksi dimana terjadinya pertukaran informasi dari komunikator kepada komunikan. Menurut rogers dan D. Lawrence Kincaid (1998:20) komunikasi adalah suatu proses pertukaran informasi yang dilakukan oleh dua orang atau lebih dimana pihak yang satu akan memberikan informasi kepada pihak yang lain dan semikian sebaliknya dan dalam hal ini keduabelah pihak akan memperoleh titik temu pada persamaan persepsi yang mendalam.

Dalam melakukan komunikasi terjadinya suatu pertukaran, pertukaran disini yaitu pertukaran pesan dan diharapkan pesan yang diterima nantinya akan sama, yaitu sama makna dan terciptalah komunikasi yang efektif. Menurut Lasswell Komunikasi memiliki setidaknya 5 unsur, Adapun unsur tersebut yaitu:

1. Sumber (source)

Sumber didefinisikan sebagai pengirim pesan, Sumber itu bentuknya dapat individu, kelompok, maupun organisasi

2. Pesan (message)

Pesan adalah hal yang akan disampaikan (dipertukarkan) kepada penerima 
pesan, biasanya berupa verbal (kata-kata) maupun nonverbal (tindakan)

3. Saluran (channel, media)

Sebagai perantara atau media yang sumber gunakan dalam menyampaikan pesan tersebut.

4. Penerima (receiver)

Nama lainnya yaitu disebut dengan komunikan, dalam hal ini alah pihak yang akan menerima pesan yang disampaikan oleh sumber.

5. Efek (effect)

Merupakan reaksi yang terjadi ketika penerima sudah mengetahui pesan dari pihak yang mengirimkan dan setelah itu dia melakukan sesuatu atas pesan tersebut.

Adapun kelima unsur yang diuraikan tersebut adalah unsur yang harus saling berkaitan satu sama lain, oleh karena itu apabila ada salah satu unsur yang tidak ditemukan maka maka tidak dapat dikatakan sebagai komunikasi. Dalam hal ini yang dinamakan komunikasi berarti harus diupayakan proses komunikasi memiliki unsur tersebut.

Selanjutnya, komunikasi juga dapat dimaknai sebagai sutu proses yang dilakukan untuk saling bertukar informasi yang saling terhubung dalam lingkungan organisasi perusahaan yang dilakukan oleh satu pihak dengan pihak lain. Selain itu secara umum komunikasi dapat terjadi secara verbal yang dapat dipahami oleh pihak yang terlibat dalam proses komunikasi tersebut. Kemudian melalui pertukaran informasi yang terjadi maka semua pihak akan dapat melakukan umpan balik yang tepat untuk dijalankan dalam rangka mencapai tujuan komunikasi dan tentu tujuan akhirnya adalah tercapainya tujuan perusahaan.

Komunikasi selain dilakukan secara verbal dan nonverbai, dapat juga dilakukan baik secara langsung maupun melalui media. Untuk melakukan komunikasi dibutuhkan media yang efektif, media komunikasi dapat berupa media cetak seperti: koran, majalah, pamflet, banne dan dapat juga melalui media elektronik seperti radio, televisi, internet. Keputusan dalam menentukan media apa yang digunakan dapat tergantung kepada konteks komunikasi yang dilakukan. Dalam perusahaan pastinya media komunikasi akan dipilih yang paling tepat guna agar dapat mencapai tujuan dari organisasi perusahaan. Melalui adanya media komunikasi yang tepat guna maka 
diharapkan semua pihak yang terlibat dalam proses komunikasi tersebut dapat berperan dan melakukan umpan balik yang terbaik sebagai upaya dalam memajukan perusahaan.

Menurut Argenti (2013) bahwa menerapkan komonikasi internal yang efektif adalah suatu cara terbaik dalam memberikan penilaian keefektifan komunikasi internal perusahaan dapat dilakukan dengan menentukan sikap karyawan terkait perusahaan. Selanjutnya, Orsini (2000) mengemukakan bahwa komunikasi internal adalah suatu kondisi dimana jika perusahaan menjalani tata kelola organisasi atau bisnis yang baik dan kontrol terhadap tujuan dari organisasi. Untuk meningkatkan efektivitas dari komunikasi internal maka sangat dibutuhkan pendekatan partisipatif berbagai pihak dalam hal ini dapat di khususkan bagi para karyawan dalam perusahaan.

Komunikasi internal sebagai proses penting yang melibatkan transfer pengetahuan dan informasi bagi organisasi serta individu untuk dapat memperoleh suatu efektivitas komunikasi internal, hal ini dapat dinilai dari beberapa variabel sebagai berikut:

(1) Komunikasi yang berlangsung dua arah merupakan bentuk komunikasi yang dijalankan secara dua arah yaitu dari pihak manajemen kepada pihak karyawan dan demikian pula sebaliknya

(2) Kemampuan interpersonal, hal ini dapat dilihat dari kemampuan yang dimiliki oleh setiap karyawan dalam menyampaikan pesan/informasi kepada organisasi

(3) Kesadaran dan juga budaya risiko

(4) Kejelasan pesan yang dilakukan antara pengirim dan penerima pesan sehingg dapat memiliki persepsi yang sama

(5) Frekuensi informasi yang dapat dinilai dari intensitas seseorang dalam memperoleh pesan atau informasi yang dimiliki

(6) Pembelajaran secara berkala yang dapat dilakukan oleh masing-masing indivu karyawan

(7) Manajemen risiko adalah pengelolaan yang dilakukan khususnya dalam hal pemantauan jenjang komite yang sudah dilakukan dan dievaluasi secara berkala

(8) Struktur komunikasi internal adalah pengorganisasian yang terdapat pada lapis pertahanan yang dilakukan untuk mengelola risiko operasional 
(9) Pengetahuan manajemen merupakan pemahaman manajemen terhadap adanya alur komunikasi yang tercipta

(10) Kekuatan leadership, dalam hal ini peran pimpinan dalam pengelolaan risiko.

Menurut Gordon dalam Encyclopaedia Britanica (2007), komunikasi adalah di mana terjadinya suatu pertukaran makna antara individu melalui sebuah sistem umum yang terbentuk dari simbol-simbol.

Dalam hal ini terjadinya perpindahan suatu pesan, informasi, ide, dan perasaan seseorang kepada individu atau sekelompok yang lain." Tidak hanya melalui kata-kata namun juga dapat dilengkapi dengan Gerakan badan maupun ekspresi wajah seperti tersenyum, marah, tertawa maupun mengangguk saat menyetujui sesuatu.

Dalam interaksi komunikasi maka terdepat beberap komponen yang menjadi satu kesatuan dalam proses komunikasi yang berlangsung, oleh karena itu komponen inilah yang membangun adanya proses komunikasi agar dapat berlangsung dengan baik. Adapun komponen yang dimaksud adalah sebagai berikut (a) Pengirim atau komunikator (sender) (b) Penerima atau komunikate (c) Pesan (massage) serta (d) umpan balik (feedback).

Tujuan Komunikasi

Effendi. Onong Uchjana (2007) menyatakan bahwa adapun tujuan dari komunikasi dilakukan agar dapat menciptakan pemahaman yang sama antara satu pihak dengan pihak lain yang melakukan komunikasi tersebut sehingga yang disampaikan pada saat melakukan komunikasi tersebut yaitu berupa pertukaran ide, gagasan maupun pemikiran pribadi dapat diterima orang lain (pihak lain) sehingga melalui proses tersebut diharapkan pihak lain dapat melakukan tindakan tertentu sesuai yang diharapkan dalam pesan komunikator.

Tentunya setiap perusahaan memerlukan sistem komunikasi yang baik dalam perusahaannya, hal tersebut harus didukung dengan ketersediaan dan kemampuan sumberdaya manusia dalam perusahaan tersebut, dalam hal ini perlu dilihat bahwa sumberdaya manusia yang baik tidak hanya dapat memahami hard skill namun juga harus mampu mengkomunikasikannya sehingga dalam hal ini kemampuan soft skill juga sangat diperlukan oleh sumberdaya manusia yang dimiliki oleh setiap perusahaan. Bahkan lebih mendalam bahwa komunikasi tidak hanya sekadar melalukan 
pembicaraan sederhana, namun kemampuan berkomunikasi dengan baik dapat dan tepat guna akan menjadi aset baik bagi perusahaan, melalui adanya kemampuan komunikasi yang baik maka sumberdaya manusia tersebut akan berdampak positif bagi lingkungannya dan akan memberikan nilai tambah bagi dirinya sendiri dan juga perusahaan. Kinerja orang yang dapat berkomunikasi dengan baik akan berpengaruh positif dan dapat membantu tercapainya tujuan perusahaan. Untuk itu kemampuan komunikasi dalam organisasi harus ditingkatkan hal ini dapat dilakukan dengan adanya training (pelatihan) yang dapat menggunakan pendekatan simulasi dan juga studi kasus yangh relevan dihadapi pada perusahaan.

Melalui adanya kemampuan komunikasi yang baik dari setiap individu di lingkungan perusahaan maka akan tercipta kondisi lingkungan kerja yang nyaman, hal ini akan berpengaruh pada kinerja yang baik dari setiap karyawan dan harapannya akan berdapak positif juga bagu perusahaan secara keseluruhan. Demikian sebaliknya, apabila kemampuan komunikasi dalam organisasi perusahaan kurang baik, maka kualitas sumberdaya manusia yang dimiliki untuk memajukan perushaan kemungkinan akan terkendala, karena buruknya interaksi dan koordinasi yang terjadi dalam setiap individu, bidang dan keseluruhan organisasi dalam perusahaan yang akan terkendala. Dalam hal ini diperlukan upaya perusahanaan dalam menciptakan iklim yang baik dan positif bagi karyawan sehingga mereka dapat berkembang dalam iklim yang kondusif serta komunikasi dan koordinasi yang berkuatas.

Gambaran dari pengertian komunikasi yang telah diuraikan akan dapat memberikan pemahaman bahwa diperlukan penelitian yang berkaitan dengan komunikasi organisasi. Jika komunikasi yang baik dan berkualitas dapat diciptakan dalam perusahaan maka bagaimana kaitannya terhadap kinerja perusahaan, hal tersebut yang akan dikaji dalam penelitian ini. Maka diharapkan melalui uraian mengenai pengertian komunikasi dapat menjadi Langkah yang terarah pada pemahaman yang mengarah pada gambaran yang sama dan kajian yang dilakukan akan menggambarkan situasi yang terjadi pada perusahaan.

\section{Fungsi Komunikasi}

Komunikasi dilakukan pasti memiliki fungsi teretntu, Adapun beberapa fungsi komunikasi dilakukan adalah sebagai berikut: 
1.Sarana menyampaikan informasi

Komunikasi dilakukan adalah sebagai sarana dalam menyampaikan pendapat seserorang (satu pihak) agar dapat diterima oleh pihak lain ataupun khalayak luas.

2. Menambah ilmu serta wawasan.

Komunikasi dilakukan fungsinya untuk menambah ilmu serta wawasan karena dalam prosesnya komunkasi akan dilakukan transfer ilmu antara pihak satu dengan yang lainnya.

3. Cara membujuk dan mempengaruhi orang lain, di mana dalam hal ini terjadi persuasif

4. Sarana hiburan, komunikasi juga dapat menghibur orang lain dan juga digunakan saat santai mengobrol ringan.

5. Sebagai usaha perubahan sikap dan juga perilaku, karena dalam komunikasi akan memberikan pengawasan serta melakukan pengendalian akan kegiatan.

6. Sebagai sarana untuk motivasi untuk orang lain, biasa digunakan oleh motivator dalam mengajak komunikannya melakukan sesuatu yang tepat.

7. Sebagai bentuk ekspresi, biasanya ekspresi wajah maupun Gerakan tubuh ( non verbal).

Tujuan dari komunikasi dapat beraneka ragam, oleh karena itu komunikasi dapat dikategorikan menjadi beberapa macam, salah satunya adalah komunikasi dalam bentuk verbal yaitu presentasu, pidato, ceramah maupun wawancara. Adapun komunikasi yang dilakukan secara verbal ini ingin menekankan bahwa komunikator memiliki peranan yang penting dalam melakukan komunikasi dan juga hasil yang diperoleh dari proses komunikasi yang dilakukan. Selain komunikasi verbal ada juga yang disebut dengan komunikasi non verbal yaitu menggunakan media seperti alat indra, body language (Bahasa tubuh) yang dapat diartikan oleh pihak lain yang melihat. Berbagai macam ragam komunikasi in dilakukan demi tercapainya pemahaman yang sama pda suatu keadaan yang menjadi pesan dari komunikasi yang dilakukan. Selain itu, ada beberapan tahapan dalam melakukan komunikasi, beberap diantaranya adalah sebagai berikut:

\section{Tahapan Komunikasi Dua Arah}

Adapun tahapan yang dilakukan dalam komunikasi dua arah memiliki beberapa 
hal, dimana pada setiap tahapan ini diperlukan keterampilan dari setiap pelaku komunikasi yang terlibat, tahapan tersebut adalah sebagai berikut:

1. Pada tahap awal pengirim pesan (source) atau sumber pesan yang sudah memiliki gagasan atau ide (pesan) akan menyampaikan pesan tersebut kepada penerima pesan (receiver). Pada kondisi ini pihak yang menjadi pengirim pesan akan memproses gagasan atau ide dasar menjadi pesan yang dapat lebih mudah disampaikan serta dipahami oleh penerima pesan. Hal ini akan berfokus pada isi pesan yang diharapkan untuk dipahami oleh penerima tanpa ada kesalahpahaman.

2. Langkah berikutnya adalah pengirim pesan akan memilih saluran komunikasi yang tepat dan sesuai konteks komunikasi yang dilakukan sehingga komunikasi tersebut dapat diterima oleh receiver, setelah menerima pesan maka receiver akan memproses pesan tersebut kemudian akan memberikan umpan balik (feed back) sebagai respon atas pesan yang diterimanya.

\section{Kelebihan dan Kelemahan Komunikasi Dua Arah}

Komunikasi dua arah memiliki kelebihan dan juga kelemahan seperti diantaranya:

1. melaluia danya komunikasi dua arah makan pesan yang disampaikan dan diterima akan lebih jelas dan akurat sebab disampaikan langsung oleh sumber pesan yang juga dapat diberikan umpan balik (feedback) oleh penerima pesan. Maka dalam hal ini kendala komunikasi yang mungkin terjadi akan dapat diminimalisir agar tidak terjadi kesalahpahaman karena penerima pesan dapat bertanya dan mengkonfirmasi langsung pesan yang didapatnya.

2. Pada situasi dan kondisi in dapat juga terjadi interaksi melalui perbincangan atau bahkan dialog antara kedua belah pihak sebagai pelaku komunikasi. Melalui adanya dialog tersebut maka diharapkan kedekatan akan terjalin dan hubungan kedekatan tersebut akan membuat komunikasi menjadi semakin baik dan menghindari kesalahpahaman yang terjadi apabila dialog tidak dilakukan secara langsung dan apabila ada hal yang kurang diapahami oleh salah satu pihak, maka dengan adanya komunikasi dua arah akan cepat terselesaikan karena dapat ditanyakan secara langsung oleh pelaku komunikasi yang terlibat (Teori Komunikasi. Jakarta: Universitas Terbuka, Mulyana. Dedi.2005) 
3. Komunikasi dua arah akan memberikan manfaat positif bagi pelaku komunikasi yang terlibat. Dimana melalui interaksi yang terjadi maka dapat memunculkan rasa keakraban bahkan kekeluargaan yang dapat juga membangun iklim demokratis dan mendukung pada kondisi yang lebih bersahabat sehingga komunikasi yang baik tersebut akan membawa dampak positef bagi pelaku komunikasinya.

\section{METODE PENELITIAN}

Metode penelitian adalah cara yang dilakukan dalam rangka pemecahan suatu masalah yang dpat menjawab tujuan suatu penelitian yang dilakukan, dimana metode akan menggambarkan secara jelas dan lengkao bagaimana proses penelitia dikerjakan dan bagaimana sistematikan teknis yang dilakukan agar permasalahan penelitian dapat terjawab. Metodologi penelitian merupakan bidang ilmu yang menguraikan seperti apa penelitan tersebut sebaiknya dilakukan sehingga segala ketentuan dan kaidah yang berlalu tersebut sesuai dengan kondisi penelitian yang dilakukan.

Penelitian yang dilakukan adalah ppendekatan deskriptif yang dapat menggambarkan komunikasi dalam sebuah organisasi perusahaan. Dimana dalam penelitian dilakukan pengumpulan informasi yang dianalisis yang diperoleh dari observasi di perusahaan dan studi literatur. Penelitian dini didasarkan pada teori komunikasi yang jelas dan diharapkan dapat menunjukkan bagaimana proses komunikasi organisasi dijalankan dan seperti apa dampaknya jika proses komunikasi itu berjalan dengan baik dan dapat dikelola oleh masing-masing individu pelaku komunikasi pada perusahaan.

Pengumpulan data yang dilakukan pada penelitian ini adalah data primer yaitu pengamatan langsung di perusahana dan data sekunder yang berasal dari berbagai literature dan penelitian sebelumnya. Kemudian dilakuakan analisis deskriptif untuk menjawab tujuan penelitian yang ada.

Adapun variabel yang digunakan adalah berdasarkan literatur dan penelitian sebelumnya yang diperoleh dari pengamatan dan data sekunder. Kemudian dilakukan interpretasi dan uraian pembahasan pada hasil penelitian tersebut secara deskriptif.

Lokasi penelitian dilakukan di unit humas Pertamina dengan memilih responden secara sengaja untuk digunakan sebagai subjek penelitia yang dapat menggambarkan 
komunikasi pada perusahaan.

\section{HASIL DAN PEMBAHASAN}

Peran kehumasan di Pertamina EP dilaksanakan oleh unit Legal \& Relations yang secara organisasi merupakan fungsi leher dari Presiden Direktur PT. Pertamina EP dan dipimpin oleh Vice President Legal \& Relations. Di level Asset / Regional, kegiatan kehumasan oleh Fungsi Legal \& Relations dikoordinasikan oleh pejabat setingkat Manager serta di level Field dikoordinasikan oleh pejabat setingkat Field Assistant Manager Legal \& Relations. Sebagai bagian dari Kontraktor Kontrak Kerja Sama (KKKS) SKK Migas, Pertamina EP melaksanakan program-program kehumasan sesuai persetujuan yang tertera di dalam Work Plan \& Budget (WP\&B) yang disetujui SKK Migas setiap tahunnya berkesinambungan untuk mendukung kegiatan operasi Perusahaan.

Terobosan demi terobosan dilakukan oleh pihak pertamina untuk dapat mengembangkan teknologi dan inovasi dalam rangka memberikan kepuasan bagi para pelanggan. Salah satu cara yang dilakukan adalah melalui aktivasi digitalisasi SPBU dan juga pengembangan Pertashop dimana pada konsepnya akan sampai pada jangkauan pertamina hingga ke seluruh daerah di Indonesia. Pada tahun 2020 menjadi target telah berjalan progam digitalisasi SPBU di seluruh Indonesia, kemudian program tersebut diharapkan akan selesai pada pertengahan tahun 2020 dari total 5.518 SPBU. Dari hasil peninjauan tahapan Civil Work tercapai sebanyak 98 persen, selain itu, kondisi dalam pembangunan instalasi Automatic Tank Gauge (ATG) sudah sejumlah 77 persen dan IT sejumlah 72 persen. Melalui program digitalisasi SPBU di seluruh Indonesia tentunya pertamina akan dapat memberikan layanan yang lebih baik kepada pelanggan sehingga akan lebih aman, mudah dan cepat.

Selain itu sebagai bentuk kontribusi kepada masyarakat sekitar perusahaan, Pertamina juga membagikan bantuan untuk Warga dan Relawan Penangan COVID-19 Pertamina menyalurkan bantuan berupa paket sembako, Alat Pelindung Diri dan sarana lain kepada warga terdampak dan relawan penanganan COVID-19 yang tinggal di ring 1 Area kerja Fuel Terminal (FT) tepatnya di daerah Tarakan, dan bantuan ini mendapat respon positif dari masyarat setempat. 
Melalui programnya "Pertamina Peduli" juga telah menjalankan berbagai program sosial sebagai perwujudan dalam penanganan dampak Covid-19 yang terjadi dimasyarakat dengan harapan dapat membantu meringankan beban dan memutu rantai penyebarab Covid-19. Contoh kasus yang terjadi di Provinsi Riau dan Jambi dimana daerah ini termasuk pada klaster wilayah Sumatera Bagian Tengah (Sumbagteng), Pertamina telah menyalurkan bantuan lebih dari Rp 1,3 Milyar melalui unit operasi yang dilakukan langsung oleh pertamina maupun penyaluran yang dilakukan melalui anak perusahaan agar dapat menjangkau masing-masing daerah di Indonesia. Hal ini sebagai bentuk kontribusi perusahaan dalam upaya menekan angka penyebaran COVID-19, hingga saat ini Pertamina terus mendistribusikan bantuan di wilayah kerja masing-masing.

Dalam membangun komunikasi dua arah Humas di Pertamina EP dilakukan oleh Fungsi Legal \& Relations yang secara organisasi merupakan fungsi leher dari Presiden Direktur PT. Pertamina EP dan dipimpin oleh Vice President Legal \& Relations.

Hubungan baik antara humas dan lingkungan sekitar dilaksanakan melalui pembentukan pola komunikasi yang intens dengan para pemangku kepentingan di wilayah operasi melalui program stakeholder engagement serta pelaksanaan beberapa program pengembangan kemasyarakatan yang dijalankan secara berkesinambungan, baik dengan masyarakat di sekitar wilayah operasi perusahaan maupun dengan stakeholder pemerintahan yang terkait. Program ini dapat berupa bantuan sosial kemasyarakatan yang disalurkan dalam bentuk barang / tunai.

Selain itu hubungan antara atasan dan karyawan di lingkungan kerja Pertamina EP juga diatur di dalam code of conduct (etika kerja dan bisnis) serta dilaksanakan dengan memegang prinsip good corporate governance yang baik sesuai yang ditetapkan oleh perusahaan. Dan ini bisa dikatakan sebagai komunikasi dua arah dalam lingkungan kerja.

Dalam hal ini terjadi komunikasi dalam organisasi, baik itu komunikasi dalam internal organisasi pertanima maupun komunikasi dengan pihak eksternal organisasi pertamian. Salah satu contoh dalam komunikasi yang terjadi dengan pihak eksternal pertamina adalah berkomunikasi dengan publik, dalam hal ini pihak Humas juga 
mperlu melakukan komunikasi yang tepat dengan sistem komunikasi yang dapat diterima oleh pihak esternal. Dengan adanya pendekatan yang baik dan metode komunikasi serta media yang tepat maka pesan dari pihak pertamina dapat diterima oleh pihak eksternal yang mana dalam hal ini pesan tersebut disampaikan dalm tujuan yang baik dan positif bagi pentima pesannya. Komunikasi dilakukan dengan melakukan pendekatan dengan media yang juga dapat menjadi media untuk menyampaiakan pesan perusahaan bagi pihak eksternal. Komunikasi dua arah sebagai sarana mengirimkan pesan secara efektif kepada penerima dalam hal ini konsumen produk PT. Pertamina (Persero) dan untuk mendapat feedback/ respon yang kemudian diolah kembali sebagai bahan pertimbangan terhadap saran yang diterima perusahaan.

Dalam memfasilitasi pelanggan dalam mengajukan pertanyaan ataupun saran dapat menggunakan fasilitas yang disediakan yaitu Customer Care 135. Pelanggan dapat menanyakan seputar produk dari pertamina diantaranya Pelumas, LPG dan BBM. Humas melakukan evaluasi terhadap opini-opini publik yang berkaitan dengan organisasi pertamina, dan menggunakan kesempatan ini juga sebagai media komunikasi yang tepat dalam memberikan informasi yang sesuai dengan fakta dan keadaan yang terjadi di masyarakat dan dapat membantu menyampaikan pesan dengan cara-cara yang baik dan benar yang dapat memperbaiki citra perusahaan di mata publik dan masyarakat luas.

Melalui komunikasi organisasi yang dilakukan oleh pihak pertamina baik dalam lingkungan internal maupun eksternal organisasi, menunjukkan bahwa komunikasi tersebut memerluakn sebuah proses dimana dalam proses tersebut terdapat bebrapa unsur yang harus diperhatikan yaitu pengirim pesan yang dapat mengkomunikasikannya dengan baik, kemudian membuat isi pesan tersebut menarik dan sederhana sehingga dapat dengan baik diterima masyarakat (reciver)dan tentu dengan menggunakan media yang tepat, sehingg diharapkan pesan akan tersampaikan dengan sangat baik dan juga memperoleh umpan baik dari masyarakat yang juga sesuai dengan harapan perusahaan. Hal ini dapat dilakukan dengan baik melalui penerapan proses komunikasi dalam organisasi yang efektif sehingga diperoleh hasil yang baik. 


\section{KESIMPULAN}

Penerapan komunikasi dua arah yang efektif yang dilakukan Humas Pertamina adalah dengan menjalin hubungan baik antara humas dan lingkungan sekitar perusahaan Pertamina EP dilaksanakan melalui pembentukan pola komunikasi dua arah dengan masyarakat maupun konsumen diantaranya dengan customer care 135 Pertamina sehingga konsumen dapat menyampaikan keluhannya, selain itu saat ini Pertamina juga melakukan berbagai digitalisasi guna memberikan layanan yang lebih memudahkan konsumen. Selain itu Pertamina juga berkontribusi langsung pada kegiatan sosial seperti memberikan bantuan ke berbagai daerah sebagai upaya pencegahan dan memutus rantai covid-19 di sekitar wilayah operasi.

\section{SARAN}

Humas Pertamina EP terus mengembangkan pola komunikasi dua arah agar tercipta iklim komunikasi yang bai kantar masyarakat maupun para pemangku kepentingan.

\section{DAFTAR PUSTAKA}

\section{Book}

Cengara, \& Hafied. (2011). Makalah Pengantar Ilmu Komunikasi. Jakarta: Rajawali.

Effendi, \& Uchjana, O. (2010). Ilmu Komunikasi dan Praktek. Bandung: PT. Remaja Rosdakarya .

Moeleong, \& Lexy. (2012). Metodologi Penelitian Kualitatif dan RED. Bandung: Alfabera. Mulyana, \& Dedi. (2011). Ilmu Komunikasi Suatu Pengantar. Bandung: PT. Remaja Rosdakarya.

Sendjaja, \& Djuarsa. (2011). Teori Komunikasi. Jakarta: Universitas Terbuka.

Veitzhal, \& Rivai. (2012). Manajemen Sumber Daya Manusia Untuk Perusahaan. Jakarta PT. Raja Grafindo Persada.

Widjaya. (2010). Ilmu Komunikasi Pengantar Studi. Jakarta: Rineka Cipta.

\section{Online Articles}

No Title. (2020). https://www.pertamina.com 